\title{
Size Reduction Particle Sizing
}

National Cancer Institute

\section{Source}

National Cancer Institute. Size Reduction Particle Sizing. NCI Thesaurus. Code C113041.

A process to reduce the particle size of a material by mechanical grinding, attrition, or impact. 